\title{
Manipulation in Translation
}

\section{(Exemplified by the Intertextual Elements' Translation)}

\author{
Natalya V. Klimovich* \\ Siberian Federal University \\ 79 Svobodny, Krasnoyarsk, 660041, Russia
}

Received 20.11.2014, received in revised form 04.12.2014, accepted 19.01.2015

The paper is devoted to the study of intertextual elements' translation in terms of the Manipulation School of translation that studies translation as a mean of manipulation and its direct impact on reader's perception. The paper studies methods of translation of the largest group of intertextual elements in fiction - intertextual elements from the Bible. Based on the comparative analysis of the intertextual elements from the Bible in original literary texts in English and their translations, which were performed in the Soviet period, we can see manipulation of reader's perception by intentional omission or replacement of the intertextual elements.

Keywords: intertextuality, intertextual element, manipulation, manipulative school of translation, words and expression from the Bible, methods of translation.

Research area: philology.

\section{Introduction}

There is a conviction, shared not only by the Manipulation School representatives, but by professional translators as well that both translators and readers are manipulated. Thus, they claim that from the point of view of the target literature, all translation implies a degree of manipulation of the source text for a certain purpose. The Manipulation scholars regard translations as a "result of manipulation of the source text which is governed by the target culture" $(17$, p. 83$)$ and believe that in literary translation manipulation can not be avoided.

Translations of the fictional texts, studied in this paper, were performed in the Communist era. These translation bear clear evidence of manipulation in translation that took place due to ideological, cultural and political reasons. The study mainly focuses on manipulation in translation of the intertextual elements from the Bible that, due to ideological reasons of the Communist era, bear clear evidence of manipulation in translation of fiction at that period of time.

\section{Point of view}

Nowadays manipulation in translation is studied by many scholars both Western and Russian. The Manipulation School of translation studies first appeared in the 1980s, influenced by the works of G. Toury [22], J.S. Holmes and I. EvenZohar [6]. The name "Manipulation School" was given by the title of an anthology of essays edited by Theo Hermans "The Manipulation of

(c) Siberian Federal University. All rights reserved

* Corresponding author E-mail address: klimovich7979@mail.ru 
Literature" [8]. Studies in Literary Translation gather a number of studies by such Western scholars as André Lefevere, S. Bassnett [4], A. Dukate [5], Vehmas-Lehto Inkeri [24] etc., and, in the last decade, such Russian researches as E.Y. Kunitsyna [15] whose research is based on the ludic theory, and manipulation is considered as a play, A. Kramina [14], N.G. Kornaukhova [2], O.M. Gotlib [3], etc.

Initially, the ideas of the Manipulation School were mostly valid for literary translation, however, later, the focus shifted from written to oral and non-literary translation. The Manipulation School bases its ideas on the concept of literary polysystem which is defined as "a system-of-systems, based on the study of how systems work (i.e. systemics)" [17, p. 71]. The concept of polysystem was introduced by I. EvenZohar, who perceived "translated literature not only as an integral system within any literary polysystem, but as the most active system within it" [6, p. 118]. Understanding translation as socially contexted behavioral type of activity, the Manipulation School rejects the idea that the target text is faithful reproduction of the source text, but sees translation as a manipulation of the source text for a certain purpose and heavily draws on sociology and cultural studies, claiming that translation is manipulation, thus, it is unavoidable. A. Ducate considers manipulation in translation as "the translators / interpreter's handling of a text which results in the adaptation of the text for the Target Audience, considering the cultural, ideological, linguistic and literary differences between the cultures in contact, which takes place within a particular cultural setting and is carried out by a human agent, with the consequence of a possible influence of individual- or psychology-related factors upon the end product" [5]. Accordingly, in literary translation manipulation cannot be avoided as it always will be permeated with various sorts of ideology, and the translator will be compelled to somehow avoid or demonstrate the clashes with dominating target culture norms.

One of the important questions concerning manipulation in translation is why would a translator misunderstand and distort the original text? According to A. Kramina, there are two types of manipulation - conscious and unconscious. Thus, manipulation in translation that arises due to various ideological, economic, social, political and cultural reasons happens consciously; manipulation that happens due to ignorance of a translator is termed unconscious manipulation. Unconscious manipulation is mostly a psychological phenomenon, and occurs under the influence of psychological factors. Thus, the author writes that "the translator, striving to produce a text acceptable for the target community, has to manipulate between the various constrains under the influence of the political and literary power structures in a given society" [14, p. 37].

A. Lefevre [4] emphasizes two general constrains that influence translators $-\mathrm{a}$ translator's own (conscious or unconscious) ideology and "the poetics" dominant in the target culture, i.e. the combination of literary devices, genres, motifs, prototypical characters, situations and symbols, as well as the concept of what is the role of literature is or should be, in the social system as a whole.

F. Farahzad, T. Allameh [7] and G. Toury [23] believe that translators' behaviour is influenced by a multitude of variables, including not only age, gender or previous experience in translation, but also the position of translation within a particular culture, and the more peripheral the position is, the more translation will accommodate itself to the established models. Besides, a translator is trapped between the desire to produce a translation as close to the original text as possible and the desire to comply with the dominant requirements. 
According to A. Lefevre, the dominant role in defining translation policy belongs to ideological considerations. Thus, during certain periods of history some texts were not translated at all or had to be translated according to certain requirements. One of the best examples is the translation policy adopted by the Soviet Union, where a lot of books that didn't comply with the adopted ideology were not translated at all, or translated with numerous omissions and alterations.

To illustrate this phenomenon, in this study the attention will be focused on the intertextual elements' translation. The translations were performed during the Soviet period and reprinted for many times, thus, the modern Russian readers still deal with ideological manipulation.

Taking into account the fact that intertextual elements are easily recognized in fiction, it is possible to talk about conscious manipulation. To be more exact - about manipulation that took place due to ideological influence of the Communist era.

Most translations of British and American authors of the late $19^{\text {th }}-$ early $20^{\text {th }}$ centuries were performed during the Communist era, thus, ideological influence on translation is obvious. To illustrate manipulation in the translated Russian texts it is possible to look at translation of the intertextual elements from the Bible.

Understanding manipulation as "control or influence $\mathrm{sb} / \mathrm{sth}$, often in a dishonest way so they do not realize it" [18, p. 934], it is possible to consider manipulation in translation as psychological manipulation - a type of social influence that aims to change the perception or behavior of others through underhanded, deceptive, or even abusive tactics. Thus, in most cases readers of translated fiction do not realize that they are being manipulated while reading authors in other languages.

The translations that are studied in this paper were conducted during the Communist era, when ideological influence was especially strong. The USSR anti-religious campaign of 1928-1941 was a new phase of anti-religious persecution in the Soviet Union following the anti-religious campaign of 1921-1928.Thus, the USSR became the first state to have, as an ideological objective, the elimination of religion and its replacement with universal atheism. Religious links and references in fiction were also forbidden. Under these conditions the translators of fiction were put in a predicament, as British and American fiction of the $19^{\text {th }}$ early $20^{\text {th }}$ centuries contained a lot of religious links, but they were supposed to avoid them and, nevertheless, perform equivalent translations. These translations help to illustrate ideological manipulation - conscious manipulation that was performed intentionally. The translation units in this case are words and expressions from the Bible used in the source texts - the intertextual elements from the Bible.

Discussing possibilities and methods of translation of the intertextual elements into another language/culture, it is necessary to assume that culture itself is intertextual, and translation (in the broad definition of this term) is a constant sign of connection between different texts within one culture and in intercultural communication.

Translation of the intertextual elements from the Bible, as translation of any other intertextual element, is "a very difficult task, as it requires from the translator to study the "nuclear" and energetically strong texts of the different language levels of the original text culture and text of translation - intercultural and atemporal; texts, that are common in several cultures and culture-specific texts" [13, p. 106].

In the process of the intertextual elements' translation, according to the study by I.S. Alekseeva [1], the following results are possible: 
1) full or partial loss of intertextuality;

2) replacement of the intertextual element of the original text to the intertextual elements, with the same connotations in the translated text.

The intertextual elements from the Bible are considered universal intertextual elements [12] as they present both in English and Russian cultures and may perform the same functions in the original and translated texts and can be equivalently translated by an intertextual element of the target culture.

Thus, in the texts under study - British and American fiction of late $19^{\text {th }}$ - early $20^{\text {th }}$ centuries the following ways of intertextual elements' translation from the Bible were identified:

1. Omission of words and expression from the Bible:

"Ma sent me a card two years ago, an' last Christmas Granma sent a card. Jesus, the guys in the cell block laughed! Had a tree and an' shiny stuff looks like snow. It says in po'try:

'Merry Christmas, purty child,

Jesus meek and Jesus mild

...Underneath the Christmas tree

There's a gif' for you from me'

I guess Granma never read it. Prob'ly got it from a drummer an' picked out the one with the mos' shiny stuff on it. The guys in my cell block goddamn near died laughin'. Jesus Meek they called me after that" [21, p. 58].

- В позапрошлом году мать прислала открытку, а этим рождеством - бабка. И хохот же стоял у нас в камере! Открытка с картинкой. На картинке елка вся в блестках, будто на ней снег. Да еще стихи:

Вот пришло к нам Рождество,

Иу деток торжество,

Глянь под елку - дед Мороз

Нам подарки всем принес.

Бабка, верно, и не видала, что там написано. Купила у разносчика да постаралась выбрать какую понаряднее. Ребята в камере чуть не умерли со смеху. С тех пор так и прозвали меня «деточкой» [22, p. 29].

As we can see, the translated text doesn't have intertextual elements. Such proper names and phrases as Jesus, Jesus meek and Jesus mild are not translated into the Russian language. In this extract omission of the intertextual elements changes the meaning of the joke from the source text. Religious link with Christmas is lost for the Russian reader.

"What'd they get? God knows the lan' ain't no good. Nobody been able to make a crop for years" [21, p. 81].

- Что они еще получат? Земля истощена. У нас уже несколько лет плохие урожаи [22, p. 55].

"But they is work," Tom insisted. "Christ Almighty, with all this stuff a-growin': orchards, grapes, vegetables - I seen it. They got to have men. I seen all that stuff" [21, p. 258].

- Но здесь должна быть работа, - гнул свое Том. - Сколько здесь всего - фруктовые caдbl, виноградники, огороды!! Здесь люди нужны. Я же видел, сколько здесь всего pacmem [22, p. 258].

In other extracts from John Stainbecks' "The Grapes of Wrath" interjections God knows and Christ Almighty are ignored by the translator, thus, changing emotionality of the original version that is lost in translation. Besides, the author intentionally uses words and phrases from the Bible, showing that his heroes are religious, but this aspect of the main characters' life is not represented in the Russian version.

According to George K. Simon [20] omission is one of the forms of manipulation. He considers it as a very subtle form of lying by withholding a significant amount of the truth. This technique is also widely used in propaganda.

2. Substitution of a word or a phrase from the Bible with its analogue that has no connection with the Holy Scripture. 
She could not see why Mrs. Touchette should make a scapegoat of a woman who had really done no harm, who had only done good in the wrong way [10, p. 271].

Она отказывалась понимать, почему миссис Тачит отыгрывается на этой женщине, которая никому не сделала зла и даже делала много хорочего, хотя и дурными путями [11, р. 227].

In the extract from "The Portrait of a Lady" the idiom make a scapegoat of $s b$. is obviously identified by the translator but is consciously substituted with the verb отыгрывается. At the semantic level it has the same meaning, but, substituting idiom with the verb again changes its expressive content.

Somewhere she was tender, tender with a tenderness of the growing hyacinths, something that has gone out of the celluloid women of today. But he would protect her with his heart for a little while. For a little while, before the insentient iron world and the Mammon of mechanized greed did them both in, her as well as him [16, p. 119].

В душе этой женщины жила нежность, сродни той, что открывается в распустившемся гиацинте; нежность, неведомая теперешним пластмассовым женщинам-куклам. И вот ему выпало ненадолго согреть эту душу теплом своего сердия. Ненадолго, ибо скоро ненасытный бездушный мир машин и мошны сожрет и их обоих [17, p. 170].

"He'll kill somebody purty soon an' they'll run him down with dogs. I can see it like a prophesy. He'll get worse an' worse. Wouldn' come along with us, you say?" [21, p. 95].

- Он еще убьет кого-нибудь и дождется, что его затравят собаками. Я это наперед вижу. Чем дальше, тем все хуже и хуже будет. Говоришь, отказался с нами идти? [22, p. 71].
The Mammon - the symbol of greed in J. Lawrence's source text and prophesy in J. Stainbeck's are substituted with their semantic, but not expressive equivalents мошны and наперед correspondingly in the Russian translated versions. Getting rid of undesired biblical link the translators managed to keep equivalence with the original texts at the semantic level.

3. Giving negative connotation to a word or an expression from the Bible.

"I remember a piece of poetry, this here guy wrote down. It was about him and an' a couple other guys goin' all over the world, drinkin' and raisin' hell and screwin' around. I wisht I could remember how that piece went. This guy had words in it that Jesus H. Christ wouldn't know what they meant" [21, p. 44].

- Одни его стихи я помню. Там так было: будто он и еще двое его приятелей разъезжают по всему свету, пьянствуют, дебоширят. Эх, жалость, всего не могу повторить! Он там таких длинных слов наворочал, сам черт не разберет! [22, p. 13].

And why's the son-of-a bitch heat up so hot today? This ain't no climb. Le's look. God Almighty, the fan belt's gone! Here, make a belt outa this little piece a rope. Le's see how longthere. I'll splice the ends. Now take her slowslow, till we can get to a town. That rope belt won't last long [21, p. 142].

И как назло, вода в радиаторе прямо бурлит. И ведь не на подъеме. Сейчас посмотрим. А черт! Ремень лопнул $у$ вентилятора! Возьми веревку, привяжи какнибудь. Хватит - концы я свяжу. Теперь медленно, совсем медленно, пока не доберемся до города. Веревка долго не продержится [22, p. 124].

In these extracts the names of Biblical characters Jesus H. Christ and God Almighty are translated with черm in the first extract and $A$ черт in the second one. This technique allowed 
to keep Biblical link of the source text, but gave negative connotation to the positive statements. Thus, having recognized the intertextual elements the translator, following the Soviet ideology conveyed them with the negative analogues, changing expressive content of the main characters' statements and, consequently, readers' perception.

4. Substitution of Biblical expressions with particles:

Rose of Sharon turned to put the dish away. Tom pointed at her. "My God, she's a-getting' big," he said.

Rose of Sharon blushed and took another dish from Ma [21, p. 342].

Роза Сарона сунула вытертую тарелку в ящик. Том сказал:

- Ну и толстеет она у нас!

Роза Сарона вспыхнула и взяла у матери вторую тарелку [22, p. 356].

Interjection with the Biblical link My God is substituted with the particle $\mu y$ in the target text. In this case expression from the source text is conveyed in the target text, the main character is surprised in both texts, but there is no equivalence at the semantic level.

Tom laughed. "By God, if he lives to be two hundred you never will get Grampa house broke," he said. "You're all set on goin', ain't you Grampa?” [21, p. 118].

Том засмеялся.

- Да такой хоть до ста лет доживет, его все равно не обуздаешь, - сказал он. Значит, в путь-дорогу, дед? [22, p. 97].

Here, interjection By God from the source text is translated by the particle Да. In this case, the technique used for translation changes the source text both at semantic and expressive levels.
Thus, texts analyzed bear direct evidence of conscious manipulation - translators avoid using intertextual elements from the Bible, substitute them or give them negative connotations. In most cases (substitution or giving negative connotation) intertextual elements are definitely identified by the translators, but are not translated with their equivalents. Such techniques lead to full or partial loss of intertextuality and, according to G.K. Simon, are aimed at naïveté - victims find it too hard to accept the idea that some people are cunning, devious and ruthless or are "in denial" if he or she is being victimized [Simon, 1996]. The same is with the translated texts - not having a possibility to read fiction in the language of the source texts, the readers sincerely believe that they read equivalent versions of British and American books.

\section{Conclusion}

Although the author of this paper had no chance to study translators' discourses (unfortunately translations under study have translators' notes, but are not provided with translators' commentaries), and understand the reasons for the choice of a technique used, the fact of manipulation is obvious. Taking into account the fact that these translations were performed during the Communist era, when ideology prohibited any connection with religion, even after identification of the intertextual element from the Bible the translators, due to ideological, political reasons and social influence tried to comply with the requirements of that epoch. The point is that a lot of classical books translated and printed during the Soviet period are still reprinted and edited for the modern reader. 


\section{References}

1. Alekseeva, I.S. Intertextuality Apotheosis (About Translation of the Poem by Timur Kibirov "When Lenin Was a Little Boy" Into German and About Intertextual Barrier in Translation) (“Apopheoz intertekstual'nosti (o perevode poemy Timura Kibirova "Kogda Lenin byl malen'kim" na nemetskii iazyk i ob intextual'nom bar'ere v perevode", in The Third Fedorov's Readings: $3^{\text {rd }}$ International Scientific Conference on Translation Studies "Fedorov's Readings" Collection). St. Peterburg: St. Peterburg State University Press, 2001, p. 13-19, in Russian.

2. Kornaukhova, N.G. Manipulation in Translation: Myth or Reality? ("Manipuliatsiia verevode: mif ili real'nost'?" in Translation in the Era of Post-Modernism: Scientific Papers Collection). Irkutsk: ISLU, 2009, p. 36-43, in Russian.

3. Gotlib, O.M. Manipulation of Value Concepts in Political Discourse ("Manipuliatsiia tsennostnymi kontseptami v politicheskom diskurse", in Semiometry of Significative Meanings of Culture and Society: Collection of Scientific Papers). Irkutsk: ISLU, 2011, p. 121-130, in Russian.

4. Bassnett, Susan. Constructing Cultures: Essays on Literary Translation / Susan Bassnett, Andre Lefevere. Clevedon: Multilingual Matters Ltd, 2000. 143 p.

5. Dukate, Aiga. Manipulation as a Specific Phenomenon in Translation and Interpreting. (http://www3.acadlib.lv/greydoc/Dukates_disertacija/Dukate_ang.doc - Published 2007. Accessed 15.07.2014). $32 \mathrm{p}$.

6. Even-Zohar, Itamar. The position of Translated Literature within the Literary Polysystem in Literature and Translation: New Perspectives in Literary Studies. Leuven: Acco, 1978, p. 117-127.

7. Farahzad, Farzaneh. A Gestalt Approach to Text Manipulation in Translation. (http://files. eric.ed.gov/fulltext/ED429437.pdf - Published 1998. Accessed 25.08.2014). 14 p.

8. Hermans, Theo. The Manipulation of Literature: Studies in Literary Translation. Croom Helm, 1985. 249 p.

9. Hodges, Peter. Cultural Approach to Translation Theory (http://www.translationdirectory. com/articles/article2202.php - Published 2010. Accessed 02.06.2014). 4 p.

10. James, Henry. The Portrait of a Lady. London: Marshall Cavendish Ltd., 1987. 576 p.

11. James, Henry. The Portrait of a Lady (Zhenskii portret). Translated from English by M.A. Shereshevskaia, L.E. Poliakova. M.: Nauka, 1984. 589 p., in Russian

12. Kuzmina, N.A. The Phenomenon of Literary Translation in the View of the Theory of Intertextuality ("Fenomen khudozhestvennogo perevoda v svete teorii intertekstual'nosti" in Text. Intertext. Culture: Collection of the International Scientific Conference Papers). M.: Azbukovnic, 2001, p. 97-111, in Russian.

13. Kramina, Aiga. Translation as Manipulation: Causes and Consequences, Opinions and Attitudes. (http://www.kalbos.lt/zurnalai/06_numeris/06.pdf - Published 2004. Accessed 13.09.2014). 5 p.

14. Kunitsyna, E.Iu. Shakespeare - Play - Translation (Shekspir-Igra-Perevod). Irktsk: ISLU, 2009. 384 p., in Russian.

15. Lawrence, David H. Lady Chatterley's Lover. London: Penguin Books, 1994. 365 p.

16. Lawrence, David H. Lady Chatterley's Lover (Liubovnik ledi Chatterli). Translated from English by I. Bagrov and M. Litvinova. SPb.: Azbuka-klassika, 2007. 448 p., in Russian.

17. Oxford Advanced Learners Dictionary. Oxford: Oxford University Press, 2010. 1780 p. 
18. Schjoldager, Anne. Interpreting Research and the 'Manipulation School' of Translation Studies. (http://download2.hermes.asb.dk/archive/download/H12_04.pdf - Published 2004. Accessed 29.06.2014). $25 \mathrm{p}$.

19. Simon, George K. In Sheep's Clothing: Understanding and Dealing with Manipulative People. A.J. Christopher, 1996. 122 p.

20. Stainbeck, John E. The Grapes of Wrath. M.: Progress Publishers, 1978. 530 p.

21. Stainbeck, John E. The Grapes of Wrath (Grozd'ia gneva). Translated from English by N. Volzhina. M.: Pravda Publishing House, 1989, p. 5-480, in Russian.

22. Toury, Gideon. In Search of a Theory of Translation. Tel Aviv: Tel Aviv University Press, 1980. $159 \mathrm{p}$.

23. Vehmas-Lehto, Inkeri. Many-Sided Translation Studies (Mnogogrannoe perevodovedenie). (http://www.helsinki.fi/slavicahelsingiensia/preview/sh35/pdf/39.pdf - Published 2008. Accessed 23.08.2014). $11 \mathrm{p}$.

\title{
Манипуляция в переводе \\ (на примере перевода \\ интертекстуальных элементов)
}

Н.В. Климович

Сибирский федеральный университет Россия, 660041, Красноярск, пр. Свободный, 79

\begin{abstract}
Исследование посвящено изучению интертекстуальных элементов в аспекте направления манипулятивного переводоведения, которое рассматривает переводы как средство манипуляичи и иеленаправленного воздействия на читателя. Рассмотрены способы перевода самой большой группы интертекстуальных элементов, встречающихся в художественной литературе, - библеизмов. На основе сравнительно-сопоставительного анализа интертекстуальных элементов в оригинальных английских художественных произведениях и их переводов, которые были выполнены в советское время, прослеживается манипуляиия сознанием читателя посредством ичеленаправленного опущения или изменения интертекстуального элемента.
\end{abstract}

Ключевые слова: интертекстуальность, интертекстуальный элемент, манипуляция, манипулятивное переводоведение, художественный текст, библеизмы, способы перевода библеизмов.

Научная специиальность: 10.00.00 - филологические науки. 